\title{
Second Births in Austria
}

\author{
Alexia Prskawetz, and Barbara Zagaglia*
}

\begin{abstract}
We investigate determinants of having a second child in Austria, a country which reached below replacement fertility in the early 1970s. In line with the findings for third-birth intensities by Hoem, Prskawetz, and Neyer (2001) we find that a mother's socio-demographic status like religiousness and her number of own siblings are important determinants of second-birth intensities while her socioeconomic status like educational attainment and labour force attachment before childbirth lose significance once we control for her partner's characteristics. Despite a strong two-child norm that prevailed for women of the birth cohorts we are studying, the incompatibility between motherhood and increasing labour force participation (as evidenced by lower birth intensities for mothers currently working) holds for second births in a similar way as for third births.
\end{abstract}

\section{Introduction}

Similar to other industrialised countries Austria experienced a drop in fertility from the mid-1960s to the late 1970s (Figure 1). Since then total fertility has stabilised at below replacement level, attaining a value of 1.42 in 2004. As evidenced in Figure 2, much of the decline in fertility is due to a fall in cohort parity progression rates at order two and above, i.e., in third and fourth births. (Parity progression ratios at parities 4 and 5 are very close to those for parity 3 and therefore not shown in the diagram.) The pivotal role that third births had for the fertility decline in Austria has been studied by Hoem, Prskawetz, and Neyer (2001) with particular focus on the role of mother's educational attainment, labour force attachment and family policies as determinants of the rate at which parents have a third child. Their findings indicate that much of the decline in third-birth intensity has been caused by increasing opportunity costs due to rising labour force participation among women under conditions of still unimproved compatibility of motherhood and childrearing.

\footnotetext{
* Alexia Prskawetz (author for correspondence), Vienna Institute of Demography, Austrian Academy of Sciences, Prinz Eugen-Straße 8-10, $2^{\text {nd }}$ floor, A-1040 Vienna, Austria. Email: alexia.fuernkranz-prskawetz@oeaw.ac.at

Barbara Zagaglia, Dipartimento di Economia, Università Politecnica delle Marche, Ancona, Italy.
} 
Figure 1:

Total fertility in Austria, 1955-2003

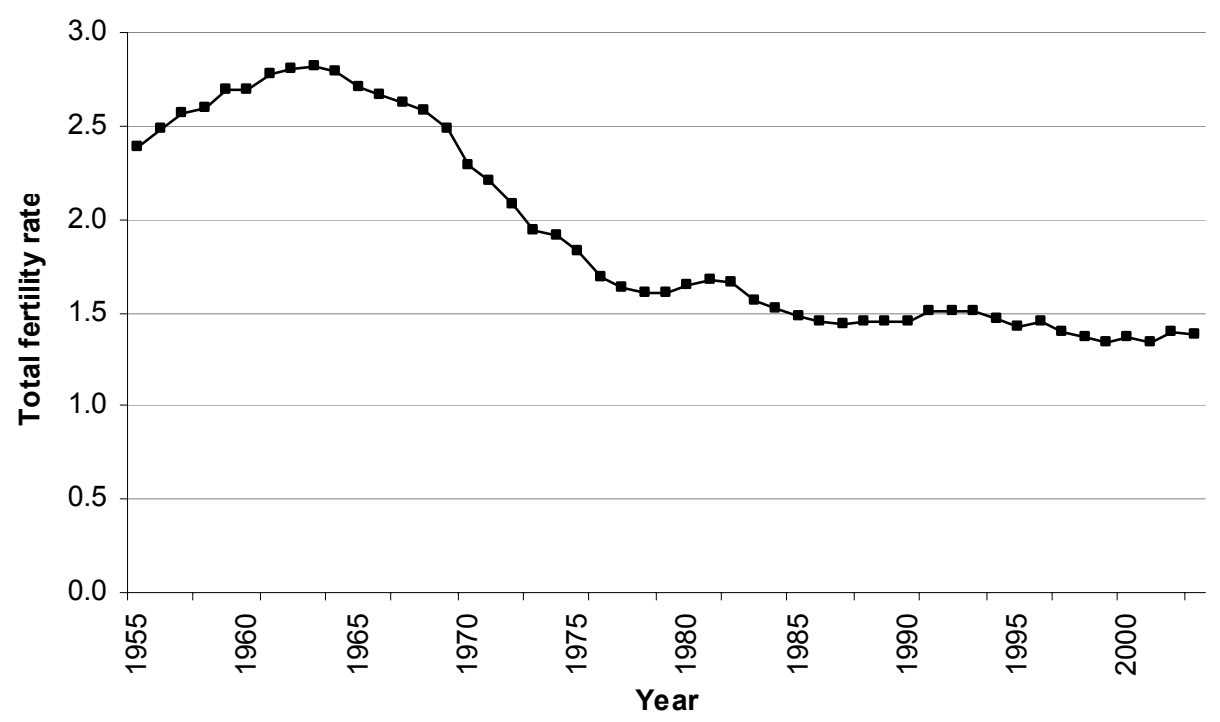

Source: Statistics Austria

To our knowledge there does not exist any in-depth demographic analysis of second-birth intensities in Austria except for some insights given in the study by Vencatasawmy (2002) and Buber and Prskawetz (2000). However, the former study focuses on the technical aspect of modelling strategies and is based on a different data source than the paper by Hoem, Prskawetz, and Neyer (2001) while the latter study focuses on the first birth event in a second union which can be a birth of order one, two or more for the respondent. An exhaustive analysis on determinants of second-birth intensities in Austria is lacking.

Given that the two-child norm is widespread in Austria (cf. Gisser et al. 1995) ${ }^{1}$ and that the cohort parity progression ratio of order one has not declined that much, one may argue that the increase in opportunity costs of childbearing over time did not produce a similar decline in second-birth intensities as observed for third-birth intensities. We await variables like mother's labour force attachment and calendar period to be less significant or at least to show up a smaller negative effect on second-birth intensities as compared to third-birth intensities. Similarly, we expect the effect of variables that represent strong family orientation (religiousness, number of respondent's siblings) to be less significant for second births as compared to third-birth intensities, having in mind that strong values of family formation are not a key determinant of second births.

At least this holds for the cohorts of women studied in the Family and Fertility Survey on which our study is based. However, in a recent paper Goldstein, Lutz, and Testa (2004) found evidence that in the German-speaking parts of Europe the average ideal family sizes given by younger men and women have fallen as low as 1.7 children. 
Figure 2:

Probability of having a(nother) child by current parity. Austrian women born in 1925 to 1960

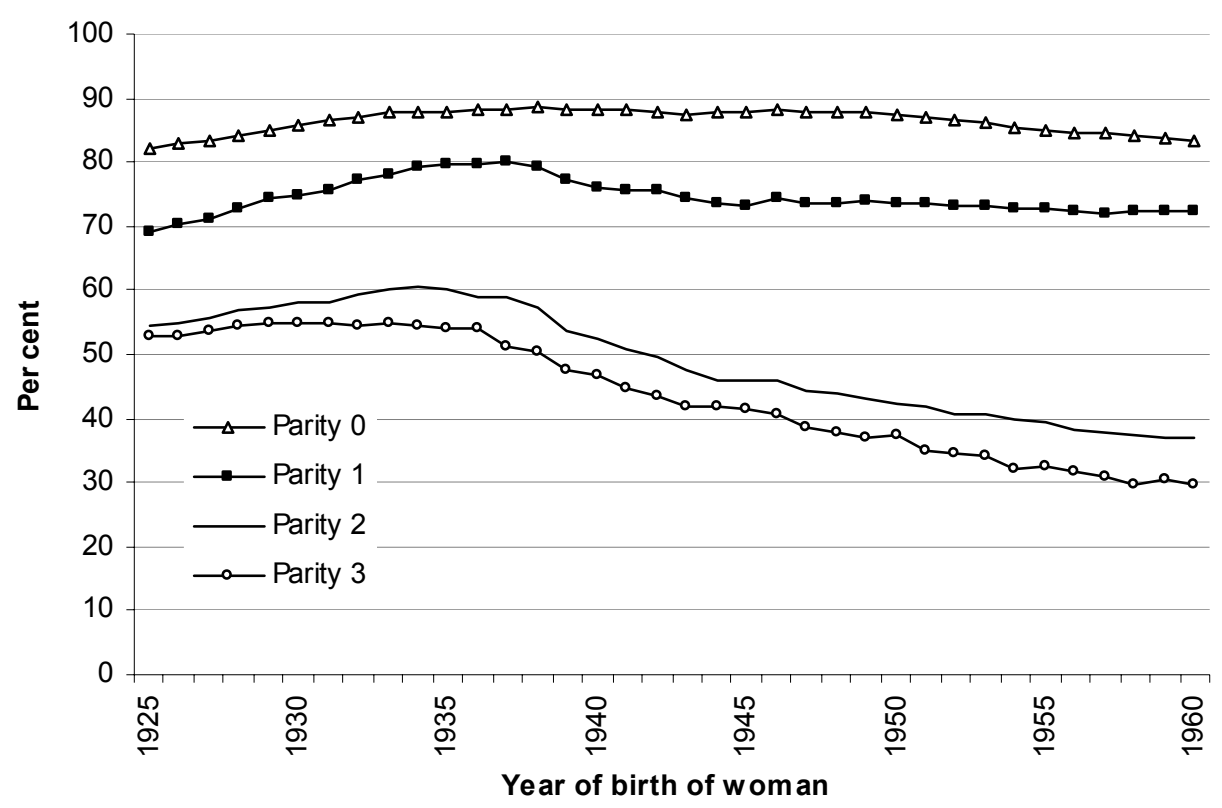

Source: Statistics Austria (2005).

While Hoem, Prskawetz, and Neyer (2001) restrict their study to women who had at least two surviving children from the same marital or non-marital union (which the authors term their birth union) we study second-birth intensities also for women who do not record any union or who have their first and/or second child in a higher-order union. By doing so, we account for the increasing risk of union instability over time. As summarised in Buber and Prskawetz (2000) not only has the share of non-marital fertility risen from 18 per cent in 1980 to 30 per cent in 1998, but also the total divorce rate increased from 18 per cent in 1970 to 26 per cent in 1980 and 39 per cent in 1998. A cross tabulation of marriages in Austria by the family status of each partner at the time of marriage in 1998 reveals that in three out of ten marriages at least one of the partners was divorced or widowed. Among couples who divorced in 1998, 34 per cent had no children, 30 per cent one child, 27 per cent two children, and 9 per cent three or more children. As these numbers indicate, neglecting second-birth intensities for women out of a union and women in higher-order unions may produce a bias for our understanding of the trend in the progression to a second child.

In our empirical analysis we therefore distinguish between two different samples. In a first step we study second-birth intensities in birth unions (i.e., children born in the same union as the first birth). We then extend the sample to include also women who record no union or different unions at the time of the first birth and in any month of observation thereafter. We expect higher birth 
intensities in new unions for the second sample, mainly basing our argument on findings in stepfamily research (cf. Buber and Prskawetz 2000 and the references cited therein). By including less traditional family forms in the second sample we can test whether our proposed determinants for second-birth intensities are stable across alternative family forms.

Second births have been studied in other European countries as well. In a pioneering study Hoem and Hoem (1989) have shown for Sweden that the transition to third births was explained by different factors as the transition to second births. While the woman's employment status, her educational level and her civil status were the most significant determinants for second births, what was most important for third-birth intensities was demographic variables. For both events the results indicate that housewives have a higher birth risk compared to women with whatever labour force attachment and that education is positively correlated with birth risks. Focusing on the role that gender equality plays for fertility decisions, Olah (2003) compares second-birth intensities of Sweden and Hungary. The main finding is that in a society with stronger gender equality (Sweden) second-birth intensities are higher. Similar to Hoem and Hoem (1989), the results also evidence a higher risk of second births for higher educated women. Most of these studies refer to Scandinavian countries (e.g., Kravdal 1992 and Hoem and Hoem 1989) but evidence of a positive effect of education on the transition to higher-order births has also been found for Austria (Hoem, Prskawetz, and Neyer 2001) ${ }^{2}$ and West Germany (Huinink 2001). ${ }^{3}$ However, as recent studies have shown, the effect of education is sensitive on how models are specified. In a study by Kravdal (2001) the higher birth intensities for higher educated women were re-examined. He shows that the positive effect on educational attainment disappears if births of all orders are modeled simultaneously. The sensitivity of the effect of woman's educational attainment on second-birth intensities is also demonstrated in a study for West Germany by Kreyenfeld (2002). She finds that the higher transition rate of second births for college graduates tends to be confounded by various factors. After controlling for the partners' characteristics and including unobserved heterogeneity factors, she

2 Hoem, Prskawetz, and Neyer (2001) argue that higher educational attainment may even reduce opportunity costs of childbearing for those women since the most important employer of bettereducated women is the public sector and this sector has had more protective labour contracts than most other sectors and therefore it is easier for women to combine work and parenthood in the public sector.

3 Using data of the Family and Fertility Survey, Huinink (2001) finds for West Germany evidence for a polarization of completed fertility among college graduates, i.e., a high percentage of childless women among the college graduates but also a high percentage of women with two or more children. This aggregate level outcome may of course be consistent with either a positive or negative individual level correlation between education and fertility depending on the degree of polarization. 
finds that the positive effect of female education becomes strongly negative. ${ }^{4}$ Regional level effects on second-birth intensities are studied by Hank (2002) for West Germany. The main conclusions are similar to the study by Kreyenfeld (2002) and applying multilevel analysis the study demonstrates that regional level fertility variations are mainly caused by differences in the spatial distribution of individual characteristics. In a recent study (Kreyenfeld and Zabel 2004) determinants of second-birth risks are studied for two countries with different welfare regimes, Germany and Great Britain. The major results from this empirical analysis are that age at first parenthood constitutes the most pronounced impact on second-birth risks, women's full time work reduces second-birth risks in both countries, and similar to previous findings higher educational attainment increases birth risks. The latter effect is stipulated to be caused by different factors in both countries. For Germany the argument is that omitted partners' characteristics produced the higher risk of highly educated women while for Great Britain the authors argue that omitted job characteristics or an income effect may be more important.

As this short literature survey indicates, it will be of interest to compare our findings not only with those on third-birth intensities in Austria as studied by Hoem, Prskawetz, and Neyer (2001) but also with findings from other studies on second-birth intensities in various countries in Europe.

We proceed by presenting the data and method of analysis in the next section before we introduce our covariates in Section 3 and present our results in Section 4. We end up with a discussion in the final section.

\section{Data and method of analysis}

Our study is based on the Austrian Fertility and Family Survey (FFS) which was conducted in 1995-96 (Doblhammer, Lutz, and Pfeiffer 1997). In the survey, retrospective histories of partnerships, births, employment, and education were collected for 4,581 women and 1,539 men between the ages of 20 and 54. The overall response rate was 72 percent.

For our analysis we select records of female respondents who had at least one surviving child. We have furthermore excluded foreigners since the difference in cultural backgrounds might affect birth intensities. ${ }^{5}$ We have excluded records where the respondent adopted her first child, had twins at first birth or was over 36 years at first birth because the childbearing behaviour of those women is likely

\footnotetext{
$4 \quad$ These unobserved heterogeneous factors may represent differences in preferences, abilities and family background variables that simultaneously affect educational attainment and fertility behavior. As argued by Kreyenfeld (2002) the hypothesis would be that family-prone college graduates select themselves into the sample of women at risk of a first birth.

5 Non-Austrian women are also not representative of the foreign population due to the original sampling procedure (cf. Appendix 1 as taken from UNECE 1998).
} 
to be different from others. In addition, we excluded a small number of records because they were incomplete or obviously erroneous. We also had to delete some non-exposure records. ${ }^{6}$

We distinguish between two sample frames. In the first sample, A, we further reduce the sample size by considering only women who had their first child in a marital or non-marital union ${ }^{7}$, which we call their birth union. That is, we exclude women who did not record any partnership and among those who had at least one union we excluded those where the first child was born outside a union. In the second sample, B, we include women independent of their union status. A count of various exclusions is recorded in Appendix 2, Table A1. The number of women included in our analysis is 2,624 in sample A and 3,285 in sample B who recorded 1,761 and 2,301 second births respectively. The remaining records were censored at the death of the first child, at the date of any disruption of the birth union (in sample A), at the date of the adoption of a second child, or at interview, whichever occurred first (cf. Appendix 2, Table A2 for the count of decrements and censoring). To prevent reverse causality between the birth of a second child on the one hand and the respondent's employment, educational histories, and other time varying covariates on the other, we backdated the event under study to seven months before a second birth. This is the time when the respondent must have been sure she was pregnant and finally decided to carry the pregnancy to term. For the same reason, the pregnancy with a second child at interview is censored by an identical mode. ${ }^{8}$ For the first birth we used the recorded month of birth.

We model the intensity of the conception of a second child using a piecewise constant exponential model (see Blossfeld and Rohwer 1995):

$$
h(t)=\exp \left(\alpha_{l(t)}+A(t) \beta\right)
$$

Here $l(t)$ is the number of the interval of constancy that contains time $t$, and $\alpha_{k}$ is a constant associated with the $k$ th time interval. $A(t)$ denotes a row vector of categorical covariates (including also time-varying covariates, which may change their value over the process time), and $\beta$ represents the associated column vector of coefficients assumed not to vary across time intervals. Our analysis produces maximum-likelihood estimates for the regression coefficients of the intensity model, which are presented in the form of relative risks.

We split the duration variable (age of first child or months since first birth) into seven time intervals: less than one year, 1 year, 2 years, 3 years, 4 years, 5 to

\footnotetext{
Records with no exposure are those where the first child is born in the month of interview, where the first child died immediately after its birth (same month), or where the union dissolved at the birth of the first child.

7 A union is defined as a co-residential relationship.

8 We censored women who are pregnant at interview since we are not sure whether the pregnancy will result in a live birth.
} 
6 years, and 7 or more years. Within each of these seven time intervals transition rates are assumed to be constant, but we allow transition rates to vary across the intervals. In a first step, we postulate that only the baseline transition rate-as given by the interval-specific constant transition rates $\alpha_{k}$ - can vary across time intervals and that each covariate has the same proportional effect in each time interval. In a second step, we test for interactions between covariates and the duration parameter. The latter extension allows us to test whether the proportionality assumption of the regression model is justified for each of the covariates under investigation.

We apply the program ROCANOVA (Martinelle 1993) which implements the maximum likelihood estimation of the coefficients of the transition rate model. For a comprehensive review of event history analysis as connected to indirect and direct standardisation in demography see Hoem (1987).

We run regressions in a stepwise manner entering covariates in a systematic sequence. Causally more distant factors are entered before ones that are causally closer to the childbearing behaviour that we study. We exclude covariates if their removal constitutes a harmless misspecification (Hoem 1992, 1995), i.e., if their effect coefficients are not affected by the presence of other covariates and, in turn, the effect coefficients of other covariates are not affected by the removal of these covariates. Detailed results can be obtained from the authors on request. In the following sections we only present the final models.

\section{Covariates}

Variables that we control for and that are expected to influence fertility behaviour are drawn from theory and from empirical research. ${ }^{9}$ We have grouped our regressors into four categories (cf. Appendix 2, Table A3):

- those that account for social background (number of siblings, religiousness);

- those that control for the respondent's and her partner's demographic characteristics (respondent's age at first birth, partner's age at birth of first child, number of current union, civil status and new union at any month of observation);

- those that account for educational attainment and labour force behaviour of the respondent and any partner (education of partner attained at start of birth union, respondent's employment history, respondent's educational attainment and current job status at any month of observation);

- those that account for business cycle and public policies (calendar period at any month of observation)

9 In particular, our starting point is Hoem, Prskawetz, and Neyer $(1999,2001)$. 
The distribution of our data across the levels of various representations of these variables can be obtained by the authors on request.

We expect individuals with a religious inclination and those who grew up with many siblings to have a higher second-birth rate, bearing in mind that these are women with a stronger family orientation. Similar to Hoem and Hoem (1989) we assume religiousness to be a stable personal trait and therefore the fact that religiousness is measured at the time of the interview should not distort our results.

One of the most stable findings in fertility analysis is that the age at first birth has a pronounced effect on subsequent fertility events. We expect those who start childbearing at earlier ages to represent individuals with a higher priority on family life and subsequently to show up as having an increased risk of higherorder births. We therefore control for the respondent's and partner's age at first birth.

Since marriage remains an important indicator of a family-oriented life style we also include a covariate to control whether the woman lived in a marital or non-marital union in any month of observation (sample A) or alternatively in no union (sample B). To take account of the fact that fertility in higher-order unions may differ from fertility in a first union (cf. Buber and Prskawetz 2000), we also control for the order of the current union. In case of sample A, married women account for almost 90 per cent and women in a first union for almost 88 per cent of the time to exposure to the risk of a second birth event in our data. For sample B these numbers decrease to 68 per cent (married women) and 73 per cent (first union). By including union order as a control variable in both samples we may test whether the increased risk of a second child often found in stepfamilies (where the second child is at least the first child to one partner) also prevails in higher-order birth unions where the first child is born (sample A) and which is a higher-order union of at least one partner, but not necessarily a stepfamily (sample B). In case of sample B we also include a variable new union that records whether the current union is different to the birth union in which the first child was born. This variable allows us to test properly for the increased risk of a second child often found in stepfamilies.

We consider the woman's and her partner's age at first birth as time-constant covariates while civil status, union number and new union are allowed to vary over the process time.

We exclude the birth cohort of respondent as an explanatory variable since this variable is perfectly co-linear to the variables age and calendar period. Having to decide between the variable cohort and calendar period we prefer to control for the only variable counting for business cycle and changes in family policy.

We controlled for educational attainment of the respondent (in any month of observation) as well as of the partner (at union formation). In both cases we have 
grouped their educational level by attainment into (i) basic schooling (up to 9 years), (ii) lower secondary education (includes apprenticeships and normally between 10 and 12 years of schooling), (iii) upper secondary education which encompasses the Austrian gymnasium and its equivalents, such as corresponding non-academic vocational training at a similar level (Berufsbildende höhere Schule), and (iv) tertiary education (including postgraduate studies, the training of teachers for primary school and for the gymnasium, training in art academies, and so on). ${ }^{10}$ We assume the educational level of the partner to reflect an income effect, i.e., we expect that the family can better afford a second child and will have a higher second-birth rate if the partner is higher educated.

The role of the mother's educational attainment is not clear a priori. While postponement of fertility may commonly be associated with a substantial increase in women's investment in higher or professional education (in response to increased returns to human capital, improved access to the labour market and more effective contraception (Kohler, Billari, and Ortega 2002), higher education may not affect the transition to higher-order births and completed fertility as discussed in several recent papers (cf. section one). Relying on the results of models with standard observable demographic variables as the guideline for our own study, we expect that mother's educational attainment will affect the transition to a second child either positively or not at all.

Since a woman's family orientation may show up in her employment history it is important to control for her labour force attachment before and after a birth of a child. Not only may a change in employment status before and after the birth of a child indicate her childbearing plans but it may as well give evidence of how easy it is to combine childbearing and gainful employment. We adopt the representation of a woman's employment experience from Hoem, Prskawetz, and Neyer (2001). In case of sample A, we consider three distinct employment spells: from age 15 to the start of the birth union, from the start of the birth union to the birth of the first child, and job activity during process time. For sample B, we aggregate the first two spells since not every woman may have a birth union and alternatively some women may have their two children in different unions. For each spell we only distinguish between two levels: either being employed (part or full time $)^{11}$ or not being employed at all.

The variable calendar period is included to reflect both up- and downswings in the economy and major changes in family policies (cf. Hoem, Prskawetz, and Neyer 2001, p. 254). As regards family policy, certain turning points in parental leave regulations are considered. Parental leave, in fact, has been proved to be the one measure of family policy with the strongest impact on fertility (see, for

10 We have assigned the highest of our educational levels to a respondent when she has completed twenty months of tertiary instruction.

11 For the first two spells the category "some employment" means to be employed at least one month; but for the variable "current job activity" (time-variant), we measure the women in each month of observation. 
instance, Neyer 2003). For major changes in Austrian parental leaves policies see, for instance, Hoem, Prskawetz, and Neyer (1999). Here we stress only one of the major changes shown to have been particularly important and effective. It was the extension of optional paid maternal leave until the second birthday of a child that was introduced in 1990 (before: until the first birthday). We expect higher intensities of a second birth event during periods of economic upswing and when family policies become more generous as in the last periods of our observations. In any case, we also expect the period factor to reflect the slight downward secular trend in second-birth intensities over time.

\section{Results}

\subsection{Second births in a birth union (sample A)}

We start by analysing reproductive behaviour of one-child mothers in a traditional coresidential family context, that may either be a consensual union or a marriage. We are interested in understanding which factors influence the choice of having at least two children and to what extent they do so. In particular, we shall contrast our results with the ones found in Hoem, Prskawetz, and Neyer (2001) for third births in Austria.

As expected and found in other studies, we find the second-birth intensity for women who state to be very religious to be considerably higher, i.e., by 34 per cent. The second-birth intensity for women coming from larger families (two or more siblings) is 28 per cent higher than for women without siblings (Table 1). However, these effects are rather weak compared to the findings for third births (cf. Hoem, Prskawetz, and Neyer 2001) where very religious women had an excess risk of 85 per cent and respondents with three or more siblings still had an excess risk of 43 per cent above the level of respondents without siblings. The difference may be explained by the fact that Austria is a country with a strong two-child norm (Gisser et al. 1995, pp. 50-59) and hence variables picking up some orientation towards family are more significant when it comes to a decision of having a third as to having a second child. We found these two variables to be orthogona $1^{12}$ to the other covariates. So, although they are highly significant, we have removed them in the final model with only significant covariates. ${ }^{13}$

12 We denote the variables number of siblings and religiousness to be orthogonal to the other variables included since their inclusion does not change the estimated effects of other covariates, nor does the selection of other covariates have much influence on the estimated effects of the siblings and religious variable.

13 Although we proceed with a misspecification of the intensity model by excluding the covariates religiousness and number of siblings, we know that this misspecification is harmless (Hoem 1992, Hoem 1995). 
Table 1:

Relative risk of a second birth by number of siblings and religiousness for women in a birth union in Austria

\begin{tabular}{lrc}
\hline Factors & $* * *$ & $\mathrm{p}$-value \\
Number of siblings & 1 & 0.000 \\
$\quad$ none & 1.06 & \\
$\quad 1$ & 1.28 & \\
2 or more & $* * *$ & 0.000 \\
Religiousness & 1.34 & \\
$\quad$ very religious & 1 & \\
$\quad$ less religious, not religious & 1 & \\
\hline
\end{tabular}

$* * *$ highly significant, p-value $=0.000 ; * *$ significant at $1 \%$ level; * significant at $5 \%$ level.

Log likelihood -9818.2 ; number of linear independent parameters 33 .

Notes: Controlled for mother's age at first birth, partner's age at first birth, civil status, age of first child, education attained by mother, partner's education, mother's labour force attachment (age 15 to the start of birthunion), mother's labour force attachment (start of birth-union to first birth), mother's current job activity, and calendar period.

Table 2 presents estimations of the final model for second births in a birth union where we mainly kept significant covariates and insignificant covariates that are related to other significant variables (as demonstrated later on by regressions where we include various interactions between covariates). Among the variables that turned out to be nonsignificant and thus are omitted are the labour market participation of respondents before entering motherhood (the spells between age 15 and the start of a birth union, and between the start of the birth union and the birth of the first child) as well as the mother's educational attainment (we will return to the latter variable in the following). Though calendar period also turned out to be non-significant we include this variable since it is significant in an interaction with the duration variable (presented later on). Note that the period factor is significant for third-birth intensities (cf. Hoem 2001) for which there is a much stronger decline in births across cohorts (as evidenced in Figure 2 in the introduction).

Demographic variables as the age of the mother and the partner at first birth play a role in explaining the transition to a second child for women in a birth union. As expected, the relative risk decreases with age. While both ages are highly significant if considered separately, the importance of the mother's age declines when her partner's age is included, and vice versa (Table 3 ).

Interactions between age of first child and either mother's age or partner's age at birth of first child improve the fit of the model. ${ }^{14}$ Distributions pass from generally two peaks for younger parents to one peak and clearly shorter birth intervals for the older ones.

14 Detailed figures on interactions can be obtained from the authors on request. 
Table 2:

Relative risk of a second birth by mother's age at first birth, partner's age at first birth, civil status, number of current union, age of first child, partner's education, mother's current job activities, and calendar period for women in a birth union in Austria

\begin{tabular}{|c|c|c|}
\hline Factors & & p-value \\
\hline Mother's age at birth of first child & $*$ & 0.019 \\
\hline $15-19$ & 1 & \\
\hline $20-21$ & 1.02 & \\
\hline $22-23$ & 1.13 & \\
\hline $24-26$ & 0.96 & \\
\hline$>=27$ & 0.84 & \\
\hline Partner's age at first birth & $* *$ & 0.006 \\
\hline$<=22$ & 1 & \\
\hline $23-24$ & 1.00 & \\
\hline $25-26$ & 0.98 & \\
\hline $27-29$ & 0.78 & \\
\hline$>=30$ & 0.84 & \\
\hline Civil status & $* * *$ & 0.000 \\
\hline cohabiting & 1 & \\
\hline married & 2.01 & \\
\hline Number of current union & $* * *$ & 0.000 \\
\hline 1 & 1 & \\
\hline 2 & 0.69 & \\
\hline $3+$ & 0.60 & \\
\hline Age of first child & $* * *$ & 0.000 \\
\hline$<1$ & 1 & \\
\hline 1 & 2.32 & \\
\hline 2 & 2.36 & \\
\hline 3 & 1.77 & \\
\hline 4 & 1.02 & \\
\hline 5 and 6 & 1.11 & \\
\hline$>=7$ & 0.20 & \\
\hline Partner's education & $* * *$ & 0.000 \\
\hline basic & 1 & \\
\hline lower secondary & 0.84 & \\
\hline upper secondary & 1.00 & \\
\hline tertiary & 1.35 & \\
\hline Mother's job activity & $* * *$ & 0.000 \\
\hline not employed & 1 & \\
\hline employed & 0.73 & \\
\hline Calendar period & & 0.216 \\
\hline $1960-1973$ & 1 & \\
\hline 1974-1979 & 0.85 & \\
\hline $1980-1987$ & 0.86 & \\
\hline $1988-1990$ & 0.86 & \\
\hline 1991-1992 & 0.84 & \\
\hline 1993-1996 & 0.83 & \\
\hline
\end{tabular}

$* * *$ highly significant, $\mathrm{p}$-value $=0.000 ; * *$ significant at $1 \%$ level; * significant at $5 \%$. Log likelihood -9863.4; number of linear independent parameters 27. 
Our regression further exhibits that being married more than doubles the risk of having a second child, compared to cohabiting couples. Similarly, the risk of having a second child is higher if it is the mother's first union as opposed to a higher-order one. Marital status and the stability of unions are therefore strong indications of family building in Austria, at least during the life segment we consider in our analysis.

Table 3:

Relative risk of a second birth by mother's and father's age at first birth in different models for women in a birth union in Austria

\begin{tabular}{|c|c|c|c|c|c|c|}
\hline \multirow[b]{2}{*}{ Mother's soe at } & \multicolumn{2}{|c|}{ Model 1} & \multicolumn{2}{|c|}{ Model 2} & \multicolumn{2}{|c|}{ Model 3} \\
\hline & & & & & & \\
\hline birth of first child & $* * *$ & 0.000 & & & $*$ & 0.019 \\
\hline $15-19$ & 0.94 & & & & 0.88 & \\
\hline $20-21$ & 0.93 & & & & 0.90 & \\
\hline $22-23$ & 1 & & & & 1 & \\
\hline $24-26$ & 0.80 & & & & 0.84 & \\
\hline$>=27$ & 0.68 & & & & 0.74 & \\
\hline $\begin{array}{l}\text { Partner's age at } \\
\text { birth of first child }\end{array}$ & & & $* * *$ & 0.000 & ** & 0.006 \\
\hline$<=22$ & & & 1 & & 1 & \\
\hline $23-24$ & & & 1.02 & & 1.00 & \\
\hline $25-26$ & & & 1.00 & & 0.98 & \\
\hline $27-29$ & & & 0.76 & & 0.78 & \\
\hline$>=30$ & & & 0.77 & & 0.84 & \\
\hline Log likelihood & -9870.7 & & -9869.3 & & -9863.4 & \\
\hline Independent parameters & 23 & & 23 & & 27 & \\
\hline
\end{tabular}

*** highly significant, p-value $=0.000 ; * *$ significant at $1 \%$ level; *significant at $5 \%$.

Notes: Controlled for civil status, number of current union, age of first child, partner's education, mother's current job activity, and calendar period.

For educational attainment we find similar results as Hoem, Prskawetz, and Neyer (2001) found for third births. Firstly, the significance of the educational attainment of mothers is lower than that of the partners' educational attainment and it loses significance once we add both variables into our regression (Table 4). In particular, a high educational attainment of women mainly appears to function as a signal about their partners' high educational level. The effect coefficients of the partners' education finally suggest that, in a similar way as for third births (cf. Hoem, Prskawetz, and Neyer 2001), one may distinguish two cultures in childbearing behaviour in Austria. In families where the partner has either no more than basic or higher educational attainment, second-birth intensities are elevated when compared to families where the husband has lower or upper secondary education. The elevated second-birth intensity for families where the partner has higher educational attainment may represent a positive income effect on second births and is more pronounced than a similar effect for third births in Hoem, Prskawetz, and Neyer (2001). Figure 3 shows that this positive effect 
appears as higher birth intensities at the very short duration since the first birth. Evidently highly educated couples have their second child at a faster pace.

Table 4:

Relative risk of a second birth by education attained by the mother and her partner in different models for women in a birth union in Austria

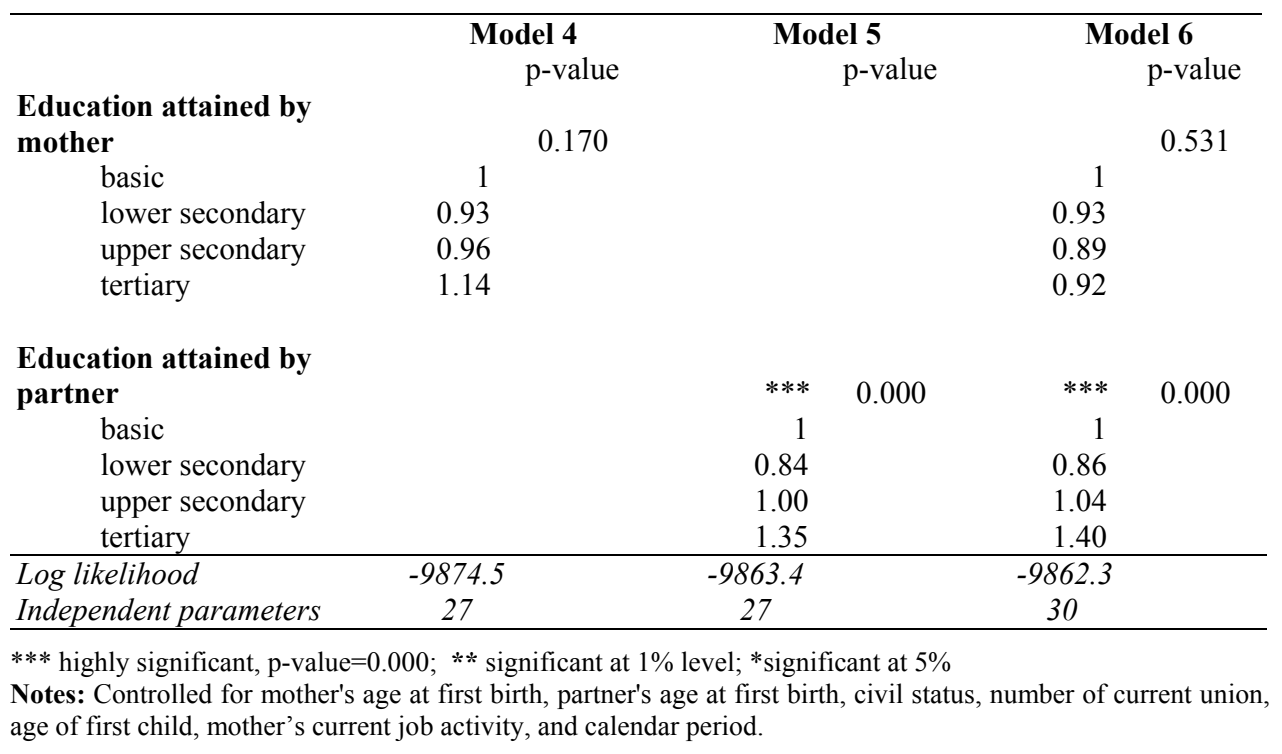

Figure 3:

Relative risk of second birth by partners' education and age of first child for women in a birth union

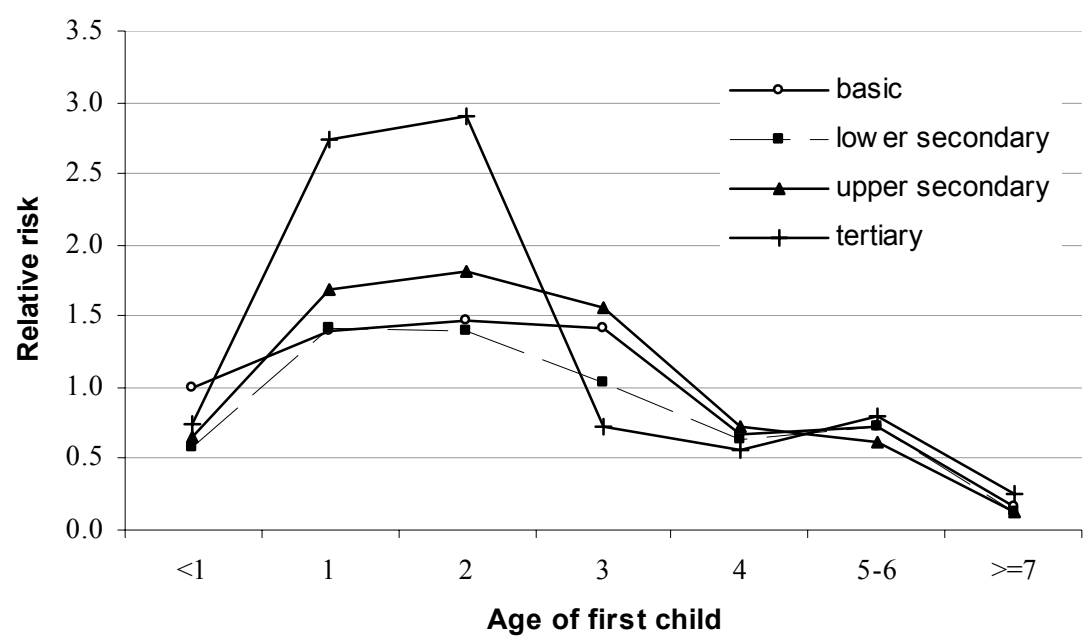

Note: Data are standardised for mother's age at birth of first child, partner's age at birth of first child, civil status, number of current union, mother's job activity, and calendar period (p-value 0.068). 
For mothers' labour force participation we again find similar results as for third births in Hoem, Prskawetz, and Neyer (2001). The effect of the labour force attachment before the birth of the first child is not significant. For women who are not employed after the birth of their first child, the relative risk of a second child is elevated by $37 \%$ compared to one-child mothers who are currently employed. We may argue that the first category are women who plan for a second child and therefore abstain from labour force participation for some time. In opposition to the findings in Hoem, Prskawetz, and Neyer (2001) we do not find any substantial difference in the speed of childbearing for second births between employed and non employed mothers.

As commonly found, our results (Table 2) also indicate a non-monotonic relation between second-birth intensity and age of first child. Similar to third-birth intensities, relative risks for second births peak at the first/second year of the previous child and thereafter decline.

Although the variable calendar period is not significant (Table 2), we found a similar interaction result as in Hoem, Prskawetz, and Neyer 2001 for the period 1993-1996 when considered together with the age of the first child (duration variable) (Figure 4; in order not to clutter up the diagram, we have left out the curves for 1974-79, 1980-87, and 1988-90 which are qualitatively similar to the one for 1960-73). Unlike Hoem, Prskawetz, and Neyer (2001) who found a prolongation of third-birth intervals between 1960-1973 and 1991-92, we observe no such postponement for second-birth intensities. However, for 1993-96 our results are in accordance to their findings: the curve of second-birth intensities moves toward shorter birth intervals. As extensively discussed in Hoem, Prskawetz, and Neyer 2001, the speeding up of childbearing may have been caused by the extension of parental leave in the mid-1990s from one to two years.

\section{Figure 4:}

Relative risk of second birth by calendar period and age of first child for women in a birth union (selected time periods)

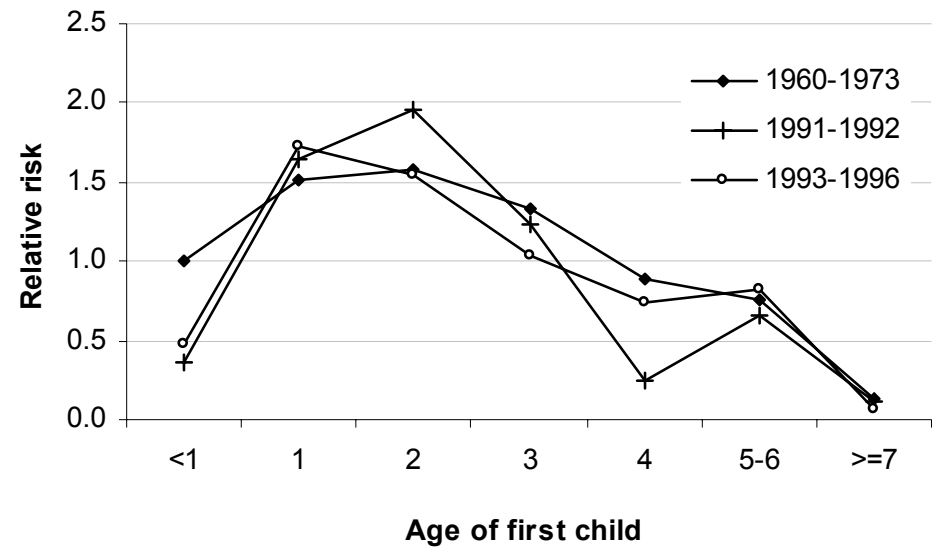

Note: Data are standardised for mother's age at birth of first child, partner's age at birth of first child, partner's education, civil status, number of current union, mother's job activity ( $p$-value 0.005 ). 


\subsection{Second-birth risks of one-child mothers in general (sample B)}

Since childbearing is not restricted to a single union and may even not be connected to a union, it is important to revise our traditional concept of families and reproductive behaviour. We therefore extend the sample design to include women whose children were not born in any union or who have experienced union breakup after the first birth. The question then arises whether second children in higher-order unions still arrive at a lower rate, as was the case for second children in first unions in our previous sample (Table 2) where we excluded stepfamilies. Since the second child of a woman might be the first child of her partner, and since the effects of a couple's attitude to childbearing may vary with their combined parity, we are interested whether the effect coefficients on the various covariates will change.

Our results indicate that the effect coefficients for siblings and religiousness (Table 5) are similar to the results where we only consider one-child mothers in a birth union (Table 1). We continue with the final model for one-child mothers (Table 6) where we only keep significant variables and those that are not orthogonal to other covariates included.

Table 5:

Relative risk of a second birth by number of siblings and religiousness for Austrian women

\begin{tabular}{crc}
\hline Factors & & \\
Number of siblings & $* * *$ & 0.000 \\
none & 1 & \\
1 & 1.06 & \\
2 or more & 1.26 & \\
Religiousness & $* * *$ & 0.000 \\
very religious & 1.30 & \\
less religious, not religious & 1 & \\
\hline
\end{tabular}

*** highly significant, $\mathrm{p}$-value $=0.000 ; * *$ significant at $1 \%$ level; *significant at $5 \%$.

Log likelihood -13343.5; number of linear independent parameters 30 .

Notes: Controlled for mother's age at first birth, civil status, number of union, new union, age of first child, education attained by mother, mother's labour force (age 15 to first birth), mother's current job activity, and calendar period.

Most of the covariates have the same effect as in the more restrictive sample we considered in the previous section. The relative risk of a second child is lower for older mothers and for mothers that cohabit or stay in no union at all. Up to the second birthday of the first child the relative risk of a second child increases, after that it goes down. Educational attainment of the mother is not significant and we keep it in the final model only because it had an influence on the effect coefficients of her labour force attachment. 
Table 6:

Relative risk of a second birth by mother's age at first birth, civil status, number of union, new union, age of first child, education attained by mother, mother's labour force attachment (age 15 to first birth) and current job activity, and calendar period for Austrian women

\begin{tabular}{|c|c|c|}
\hline Factors & & p-value \\
\hline Mother's age at birth of first child & $* * *$ & 0.000 \\
\hline $15-19$ & 1 & \\
\hline $20-21$ & 0.93 & \\
\hline $22-23$ & 1.00 & \\
\hline $24-26$ & 0.83 & \\
\hline$>=27$ & 0.72 & \\
\hline Civil status & $* * *$ & 0.000 \\
\hline married & 1 & \\
\hline cohabiting & 0.49 & \\
\hline not in a union & 0.37 & \\
\hline Number of current union & $* *$ & 0.007 \\
\hline 1 & 1 & \\
\hline 2 & 1.39 & \\
\hline $3-4$ & 0.86 & \\
\hline none & 1.08 & \\
\hline New union & $* * *$ & 0.000 \\
\hline no & 1 & \\
\hline yes & 1.45 & \\
\hline Age of first child & $* * *$ & 0.000 \\
\hline$<1$ & 1 & \\
\hline 1 & 2.14 & \\
\hline 2 & 2.12 & \\
\hline 3 & 1.65 & \\
\hline 4 & 1.03 & \\
\hline 5 and 6 & 1.16 & \\
\hline$>=7$ & 0.29 & \\
\hline Education attained by mother & & 0.132 \\
\hline basic & 1 & \\
\hline lower secondary & 0.93 & \\
\hline upper secondary & 0.94 & \\
\hline tertiary & 1.13 & \\
\hline $\begin{array}{l}\text { Mother's labour-force attachment, } \\
\text { age } 15 \text { to first birth }\end{array}$ & * & 0.019 \\
\hline no employment & 1 & \\
\hline some employment & 1.16 & \\
\hline Mother's job activity & $* * *$ & 0.000 \\
\hline not employed & 1 & \\
\hline employed & 0.69 & \\
\hline Calendar period & $* *$ & 0.009 \\
\hline $1960-1973$ & 1 & \\
\hline 1974-1979 & 0.82 & \\
\hline 1980-1987 & 0.81 & \\
\hline 1988-1990 & 0.82 & \\
\hline 1991-1992 & 0.82 & \\
\hline 1993-1996 & 0.78 & \\
\hline
\end{tabular}

*** highly significant, $\mathrm{p}$-value $=0.000 ; * *$ significant at $1 \%$ level; * significant at $5 \%$. Log likelihood -13361.8; number of linear independent parameters 27. 
One of the most striking differences with respect to our results in Table 2 is the change in the effect coefficients on the number of unions. If we extend our sample and also include stepfamilies, second-birth intensities are highest if the mother is currently in her second union. ${ }^{15}$ Our finding can be explained by the fact that a second child born in a second union is the first shared child in a new union of the respondent. From the literature (cf. the review in Buber and Prskawetz 2000) we know that a first shared child may confer different functions (union commitment effect for both partners, parenthood effect for the partner for which the first shared birth in a higher-order union is also his (her) first birth, sibling effect if pre-union children act as half-siblings). Our results indicate that some of these effects are strong enough to increase the relative risk of a second birth in a higher-order union.

Support to our hypothesis is given by the increased risk of a second birth for mothers who are currently living in a new union (Table 6). An interaction between the variables union order and new union (Figure 5) indicates that the elevated risk for a second birth mainly holds for mothers currently living in a second union. Moreover, as an interaction between the union order and the age of the first child (Figure 6) indicates, for mothers in unions of order two the relative risk of second births shows two peaks. The first peak is attained at a relatively young age of the first child while a second peak is obtained when the first child is already 5 to 6 years of age. We interpret this latter peak to be mainly caused by stepfamily fertility, i.e., second births of the woman that are the first birth in a new union of hers.

\section{Figure 5:}

Relative risk of second birth by new union and number of current union for Austrian women

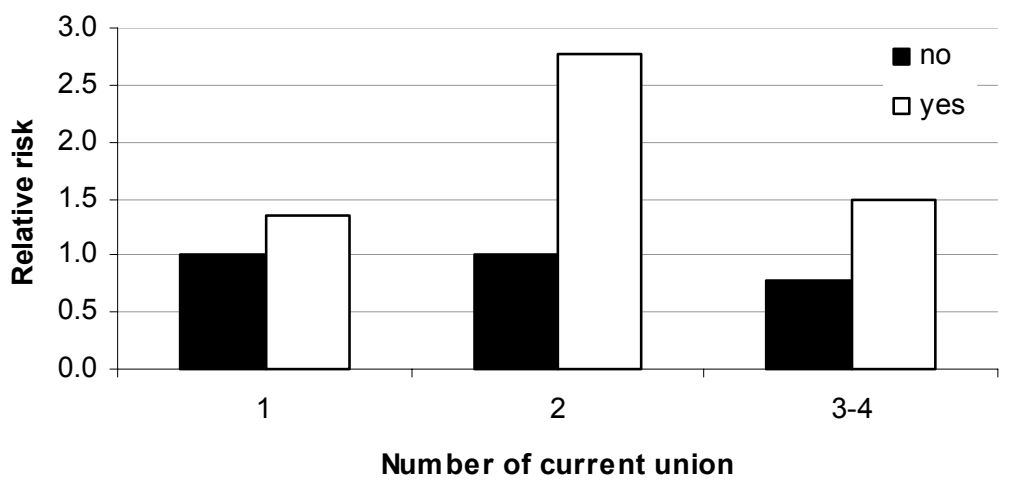

Note: Data are standardised for mother's age at birth of first child, civil status, education attained by mother, mother's labour force attachment (age 15 to first birth) and current job activity, calendar period, and age of first child (p-value 0.002)

15 No women of our sample lived in a union of order 5 or more. 
Figure 6:

Relative risk of second birth by union number and age of first child for Austrian women

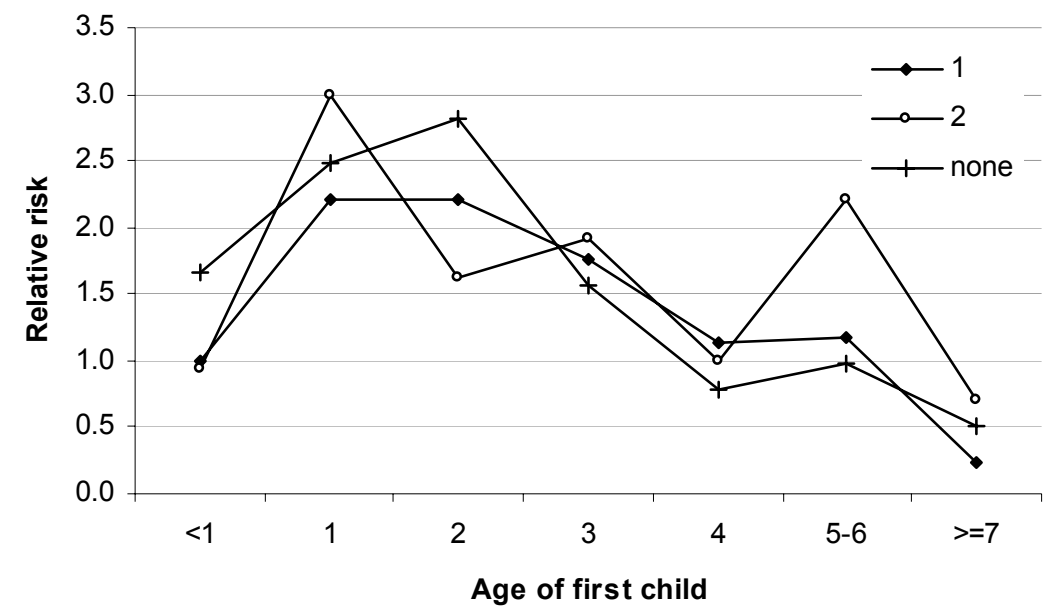

Note: Relative risks are not represented for respondents in their third or fourth union due to their very low exposure time.

Data are standardised for mother's age at birth of first child, education attained by mother, mother's labour force attachment (age 15 to first birth) and current job activity, civil status, new union, calendar period (p-value 0.001).

Calendar period and respondent's job activity between age 15 and birth of the first child become significant in the new sample with those being employed before the first birth showing a slightly higher risk for a second child. We caution to put too much emphasis on this result since it may be partly caused by not controlling for the partners' characteristics. (We aim to include partners' characteristics in our further work.)

Besides the main effects presented in Table 6, our results indicate a further significant interaction between age of first child and civil status (Figure 7) and between age of first child and employment status before the first child (Figure 8). From Figure 7 we may deduce that cohabiting mothers have a lower relative risk of a second child, independent of the duration since their last birth. ${ }^{16}$ The result that married mothers and mothers who are not living in a union show almost identical shapes of the relative risk of a second child may be related to a specific family policy prevalent in Austria. The latter result may confirm the incentive to

16 Notwithstanding the main effects obtained in Table 6, married and lone mothers have similar second birth risks in Figure 7. This may be explained by the fact that the variables union number and civil status coincide for lone mothers. Once we included the interaction civil status and age of first child the coefficient for the category "none“ for the variable union order decreased to 0.38 . Obviously the low value of the coefficient „not in a union“ for civil status in Table 6 indicates that its effect has been taken up by the coefficient „none“ for union order in Table 6. 
start living together (or to claim that this is the case) really only some time after the birth of a first shared child related to the single-mother benefit. ${ }^{17}$ Similarly the result that women with some labour market experience before the birth of their first child have a higher risk to have their second child shortly (1-2 years) after the birth of the first child could resemble specific features of the Austrian parental leave policy (Figure 8). ${ }^{18}$ Though significant, the interaction between calendar period and age of first child does not show the clear pattern of first postponing and then anticipation of second births as a consequence of a change in the length of the maternal leave period as evidenced in Hoem, Prskawetz, and Neyer (2001). It may be that women who have their first two children in the same birth union are more family oriented and are more likely to take advantage of changes in family policies through the pattern of their birth spacing.

\section{Figure 7:}

Relative risk of second birth by civil status and age of first child for Austrian women

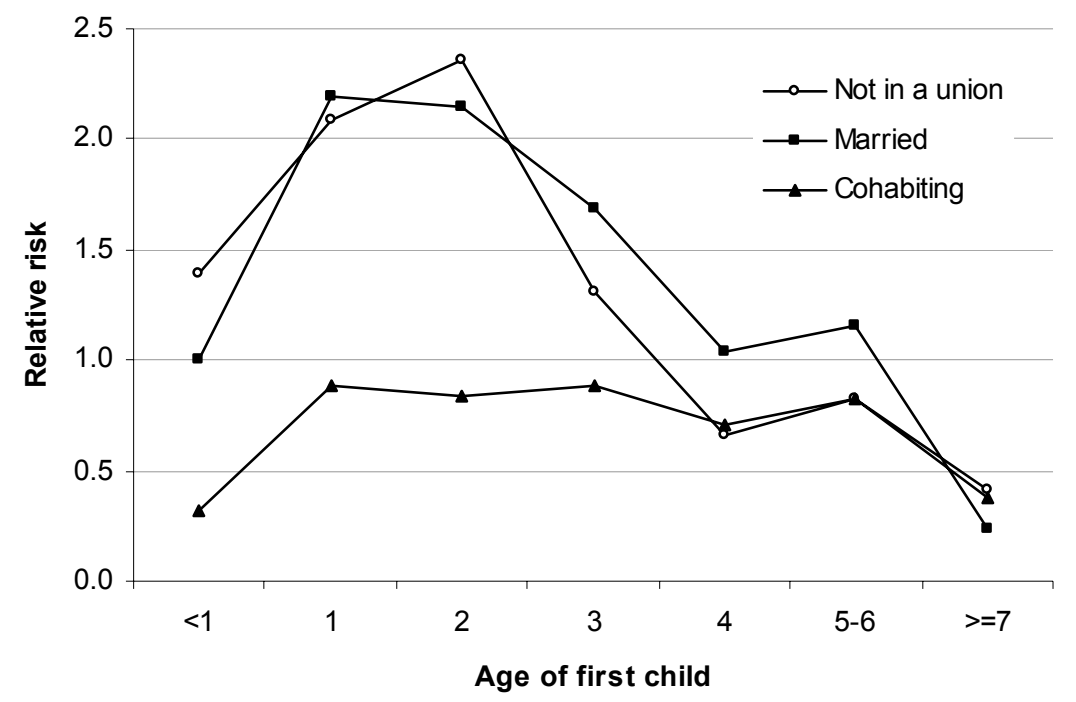

Note: Data are standardised for mother's age at birth of first child, number of union, new union, education attained by mother, mother's labour force attachment (age 15 to first birth) and current job activity, and calendar period (p-value 0.000).

A special maternity leave payment to lone mothers was established in 1984 (Vikat et al. 2004).

18 It is part of the system that employed women are required to be on (fully paid) leave from work during a mandatory maternity protection period, which lasts for 16 weeks ( 8 weeks before the projected time of delivery and 8 weeks after actual delivery). To be entitled to the maternity protection period, women must normally have worked for four weeks prior to this period. 
Figure 8:

Relative risk of second birth by labour force attachment from age 15 to first child and age of first child for Austrian women

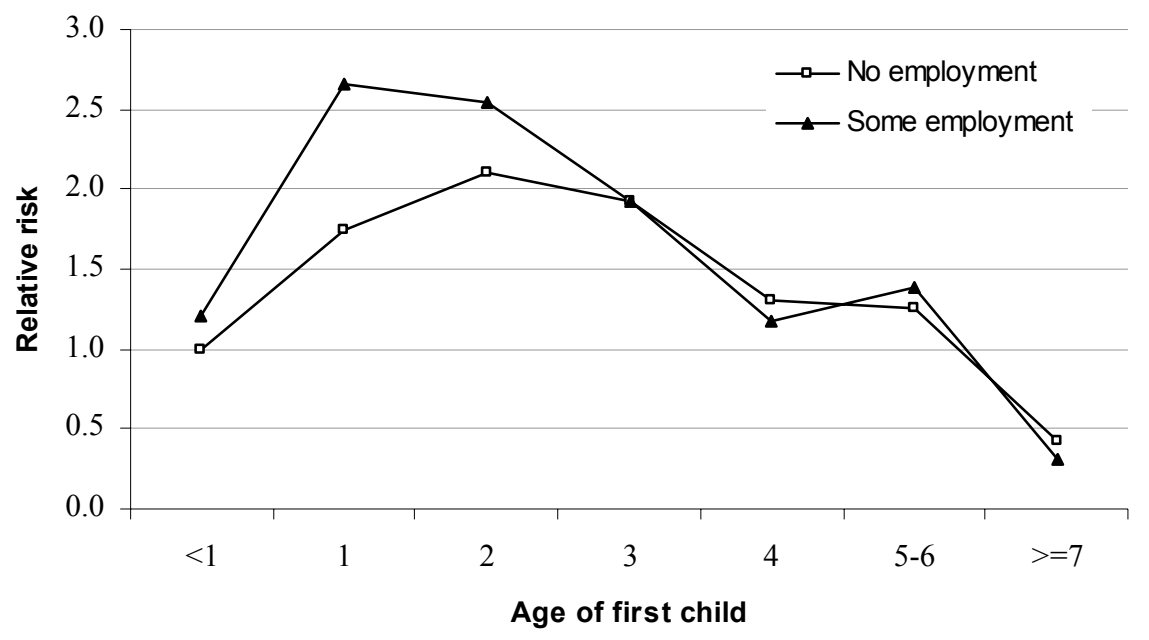

Note: Data are standardised for mother's age at birth of first child, civil status, number of union, new union, education attained by mother, mother's job activity, and calendar period ( $\mathrm{p}$-value 0.027).

\section{Discussion}

In this paper we have presented an in-depth analysis of second-birth intensities for Austrian women of birth cohorts 1941 to 1976; a population where cohort fertility declined from 2.32 children per woman of those born in 1949 to 1.64 of those born in 1965 (cf. Frejka and Sardon 2004, Table 2). At the same time a postponement of fertility took place. While 62.4 per cent of the cohort fertility was reached up to the $27^{\text {th }}$ birthday for women of the birth cohort 1940, this number declined to 51.3 per cent for the birth cohort 1965 (cf. Frejka and Sardon 2004, Table 3). Much of the decline in total cohort fertility may be explained by a pronounced decline in higher-order (3+) births (cf. Frejka and Sardon 2004, Figure 8) and an increase of the proportion of childless women from around 12 per cent for the 1940 birth cohort up to 20 per cent for the 1965 cohort. A study by Hoem, Prskawetz, and Neyer (2001) has offered a first in-depth study of the decline in third-birth intensities for Austria for women of birth cohorts 1941 to 1976 and concluded that the incompatibility of motherhood and labour activity during times of increasing educational attainment by, and labour market activity of, women has caused this pronounced drop in births of order three. Though less pronounced, a decline in cohort fertility can also be observed for second births (cf. Frejka and Sardon 2004, Figure 8). In a country with a strong two-child norm in which parity progression ratios of order one have been rather stable over the last decades (cf. Figure 2) it is therefore interesting whether the drop in second- 
birth order fertility may be explained by similar determinants as have been identified for the drop in higher-order births. In this paper we therefore studied second-birth intensities and compared the results to (a) previous findings for third-birth intensities and (b) other European studies on second-birth intensities. Our main findings can be summarised as follows:

- Social background variables are less important for second births than for third births, indicating that second births are not restricted to the same extent to women with strong values towards family formation.

- In line with previous findings, age at first childbearing plays an important role to understand higher-order birth intensities. There is a positive impact of both partners' younger age on second-birth risks.

- In line with previous findings for third births and other studies on second births we find that educational attainment of mothers loses significance once we control for their partners' educational attainment. In a country like Austria where the male breadwinner model is prevalent, the partner's educational characteristics obviously reflect an important income effect. We found this income effect to be more pronounced for second births as compared to third births.

- In line with previous findings for third births in Austria we find that a respondent's labour force attachment before the first birth does not affect birth intensities. For mothers employed during any months after the first birth we find a lower risk of a second child as compared to mothers without employment. These findings are consistent also with results found for second births in West Germany.

- Other than in the case of third-birth intensity we could not find a very pronounced postponement effect by time since previous birth over calendar period for second births. Also the fact that higher-order births have been brought forward to occur at shorter birth intervals during the period that followed the extension of maternal leave period up to the child's second year in 1990 could not be found with the same clarity as for third births.

- An extension of the sample that also includes women whose first child was not born in a union, or who were not subsequently living in the same union where the first birth was born, indicated that secondbirth intensities are higher in unions of order two. We interpret these findings as evidence for increased birth intensities in stepfamilies.

In summary, our results for second-birth intensities in Austria confirm most of the findings on second-birth intensities found for West Germany (Kreyenfeld and Zabel 2004), a country with a welfare system similar to Austria. Compared to previous findings for third-birth intensities in Austria, the determinants of second births are similar with some noteworthy exceptions such as a stronger effect of partner's educational attainment and a smaller effect of family policies and values. Despite a strong two-child norm that prevailed for women of the birth 
cohorts we are studying, the incompatibility between motherhood and increasing labour force participation (as evidenced by lower birth intensities for mothers currently working) holds for second births in a similar way as for third births.

\section{Acknowledgements}

Both authors wish to acknowledge helpful discussions with Gunnar Andersson and Maria-Rita Testa. We would like to thank two anonymous referees as well as Tomáš Sobotka and Dimiter Philipov for their comments and suggestions that made the paper more transparent.

Barbara Zagaglia acknowledges financial support from the European Union (project contract number HPRN-CT-2001-000234).

\section{References}

Blossfeld, H.-P. and G. Rohwer. 1995. Techniques of Event History Modeling: New Approaches to Causal Analysis. New Jersey: Lawrence Erlbaum Associates.

Buber, I. and A. Prskawetz. 2000. "Fertility in second unions in Austria: Findings from the Austrian FFS." Demographic Research, Vol. 3, Article 2.

Doblhammer, G., W. Lutz, and C. Pfeiffer. 1997. Tabellenband und Zusammenfassung erster Ergebnisse: Familien- und Fertilitätssurvey (FFS) 1996. Österreichisches Institut für Familienforschung, Vienna.

Frejka, T. and J.-P. Sardon. 2004. "Fertility in Austria: Past, present and the near future." Vienna Yearbook of Population Research 2004: 35-56.

Gisser, R., W. Holzer, R. Münz, and E. Nebenführ. 1995. Familie und Familienpolitik in Österreich. Wissen, Einstellungen, offene Wünsche, internationaler Vergleich. Forschungsbericht. Wien: Bundesministerium für Jugend und Familie.

Goldstein, J., W. Lutz, and M. R. Testa. 2004. "The emergence of sub-replacement family size ideals in Europe." Population Research and Policy Review 22: 479-496.

Hank, K. 2002. "Regional social contexts and individual fertility decisions: a multilevel analysis of first and second births in Western Germany." European Journal of Population 18(3): 281-299.

Hoem, J. M. 1987 "Statistical analysis of a multiplicative model and its application to the standardization of vital rates: A review." International Statistical Review 55: 119-152.

Hoem, J. M. 1992. "Harmless model misspecification.” In: O. Ljones, B. Moen, and L. Ostby (eds.) Mennesker og modeller, livslop og krysslop. Oslo: Statistik Sentralbyra, pp. 735-748.

Hoem, J. M. 1995. "Harmless omission in the standardization of demographic rates." European Journal of Population 11(4): 313-322;

Hoem, B. and J. M. Hoem. 1989. "The impact of women's employment on second and third births in modern Sweden." Population Studies 43: 47-67.

Hoem, J. M., A. Prskawetz, and G. Neyer. 1999. "Third birth in Austria: the effect of public policies, educational attainment, and labor-force attachment." MPIDR Working Paper WP 1999-002, Rostock: Max Planck Institute for Demographic Research. 
Hoem, J. M., A. Prskawetz, and G. Neyer. 2001 “Autonomy or conservative adjustment? The effect of public policies and educational attainment on third births in Austria, 1975-96." Population Studies 55: 249-261.

Huinink, J. 2001. "The macro-micro-link in demography-explanations of demographic change." Paper presented at the Euro Conference The second demographic transition in Europe, 23-28 June 2001, Bad Harrenalb, Germany. Available at $<<$ www.demogr.mpg.de/papers/workshops/010623_paper08.pdf $>>$.

Kohler, H.-P., F. C. Billari, and J. A. Ortega. 2002. "The emergence of lowest-low fertility in Europe during the 1990s." Population and Development Review 28(4): 641-680.

Kravdal, Ø. 1992. "The emergence of a positive relation between education and third birth rates in Norway with supportive evidence from the United States." Population Studies 46 (3): 459-475.

Kravdal, Ø. 2001. "The high fertility of college educated women in Norway: An artefact of the separate modelling of each parity transition." Demographic Research 5(6), $<<$ www.demographic-research.org $>>$.

Kreyenfeld, M. 2002. "Time squeeze, partner effect or self-selection? An investigation into the positive effect of women's education on second birth risks in West Germany." Demographic Research 7(2), <<www.demographic-research.org >>.

Kreyenfeld, M. and C. Zabel. 2004. "Determinants of second birth risks in Great Britain and West Germany." Manuscript prepared for the $6^{\text {th }}$ International German SocoEconomic Panel Conference in Berlin, June 24-26, 2004.

Martinelle, S. 1993. Rocanova: A program for intensity regression, Version 1.2, User's guide, Stockholm 1993.

Neyer, G. R. 2003. "Family policies and low fertility in Western Europe." MPIDR WP 2003-021, Rostock: Max Planck Institute for Demographic Research.

Olah, L. S. 2003. "Gendering fertility: second births in Sweden and Hungary." Population Research and Policy Review 22(2): 171-200.

Statistics Austria. 2005. Volkszählung 2001. Haushalte und Familien. Statistics Austria. Vienna.

UNECE UNPF. 1998. Fertility and Family Survey in countries of the ECE region. Standard Country Report. Austria U.N., New York and Geneve.

Vencatasawmy, Coomaren, P. 2002. "Modelling fertility in a life course context." ÖIF Working Paper 16.

Vikat, A., E. Thomson, and A. Prskawetz. 2004. "Childrearing responsibility and stepfamily fertility in Finland and Austria.” European Journal of Population 20: 1-21. 


\section{Appendix 1: FFS Survey Sample Characteristics}

In Austria, the sample was stratified disproportionally in order to be representative for each of the nine Austrian provinces ('Bundesländer'), in addition to Austria as a whole, so as to make regional analysis and within-country comparison possible. Within each 'Bundesland', the sample was stratified disproportionally according to sex ( 3 women interviewed for every 4 respondents) but proportionally according to municipality size. Altogether, samples were then drawn in 354 randomly selected municipalities and in all districts of the capital Vienna. The questionnaire was identical for men and women except that the male version lacked questions on abortions and stillbirths. Non-Austrian citizens were also interviewed, but Non-Austrians not fully familiar with the German language are underrepresented. Interviews were done through personal interviews and by using laptop computers that allowed permanent and immediate plausibility checks. Refusing the interview was more common in larger municipalities. As a result, the sample is likely to be biased according to socio-psychological characteristics. Non-responses were significantly higher among respondents above age 40 and/or with only lower education. Most, but not all, of the resulting under-representation of these groups was corrected by additional interviews during the final month. An interesting result regarding the validity and reliability of the interviews was obtained from interviewing the interviewers. According to their assessment, $82 \%$ of respondents gave at least reliable answers. Questions on children ever had, on fertility preferences, and on the education and occupation biographies were answered with high reliability, while the highest degree of unreliability was found on household income, and the distribution of household tasks and childcare. 


\section{Appendix 2}

Table A1:

Counts of exclusions

\begin{tabular}{|c|c|c|c|c|c|}
\hline \multicolumn{3}{|c|}{$\begin{array}{l}\text { Sample A: One-child } \\
\text { mothers in a birth union }\end{array}$} & \multicolumn{3}{|c|}{$\begin{array}{l}\text { Sample B: All one-child } \\
\text { mothers considered }\end{array}$} \\
\hline 1. & Males & 1539 & 1. & Males & 1539 \\
\hline 2. & Never lived in a union & 668 & 2. & Childless & 1062 \\
\hline 3. & Childless & 546 & 3. & Birth not ordered & 14 \\
\hline 4. & $\begin{array}{l}\text { Birth not ordered } \\
\text { chronologically }\end{array}$ & 14 & & $\begin{array}{l}\text { First child adopted } \\
\text { Twins at first birth }\end{array}$ & $\begin{array}{l}20 \\
27\end{array}$ \\
\hline 5. & First child adopted & 19 & 6. & Age of mother at birth of first & 23 \\
\hline 6. & Twins at first birth & 27 & & child $>36$ years & \\
\hline $\begin{array}{l}7 . \\
8 .\end{array}$ & $\begin{array}{l}\text { First birth out of a union } \\
\text { Age of mother at birth of }\end{array}$ & 546 & 7. & $\begin{array}{l}\text { Pregnant with } 1^{\text {st }} \text { child at } \\
\text { interview } \\
\text { No response about siblings }\end{array}$ & $\begin{array}{l}0 \\
8\end{array}$ \\
\hline 9. & $\begin{array}{l}\text { first child }>36 \text { years } \\
\text { Pregnant with } 1^{\text {st }} \text { child at } \\
\text { interview }\end{array}$ & 17 & $\begin{array}{c}8 . \\
9 . \\
10 .\end{array}$ & $\begin{array}{l}\text { No response about siblings } \\
\text { Foreign nationality } \\
\text { No exposure }\end{array}$ & $\begin{array}{c}8 \\
125 \\
17\end{array}$ \\
\hline $\begin{array}{l}10 . \\
11 . \\
12 . \\
13 .\end{array}$ & $\begin{array}{l}\text { No response about siblings } \\
\text { Foreign nationality } \\
\text { No exposure } \\
\text { No answer about partner's }\end{array}$ & $\begin{array}{c}8 \\
99 \\
13 \\
45\end{array}$ & 11. & No answer about religiousness & 12 \\
\hline & Sum & 3541 & & Sum & 2847 \\
\hline
\end{tabular}

Note: Numbers of exclusions are obtained by subtracting a set from the previous overset according to the order given in the table.

Table A2:

Count of decrements (total occurrences and censoring)

\begin{tabular}{|c|c|c|c|c|c|}
\hline \multicolumn{3}{|c|}{$\begin{array}{l}\text { Sample A: One-child } \\
\text { mothers in a birth union }\end{array}$} & \multicolumn{3}{|c|}{$\begin{array}{l}\text { Sample B: All one-child } \\
\text { mothers considered }\end{array}$} \\
\hline 1. & No second child & 544 & 1. & No second child & 920 \\
\hline 2. & Second child & 1761 & 2. & Second child & 2301 \\
\hline 3. & Second child adopted & 3 & 3. & Second child adopted & 4 \\
\hline 4. & Birth union split & 269 & 4. & First child died before interview & 15 \\
\hline 5. & $\begin{array}{l}\text { First child died before } \\
\text { interview }\end{array}$ & 9 & 5. & $\begin{array}{l}\text { Pregnant with second child at } \\
\text { interview }\end{array}$ & 45 \\
\hline 6. & $\begin{array}{l}\text { Pregnant with second child at } \\
\text { interview }\end{array}$ & 38 & & & \\
\hline & Sum & 2624 & & Sum & 3285 \\
\hline
\end{tabular}

Note: Counts of decrements are presented as calculated before dropping the missing values about partner's age (Sample A) and religiousness (Sample B). 
Table A3:

List of covariates

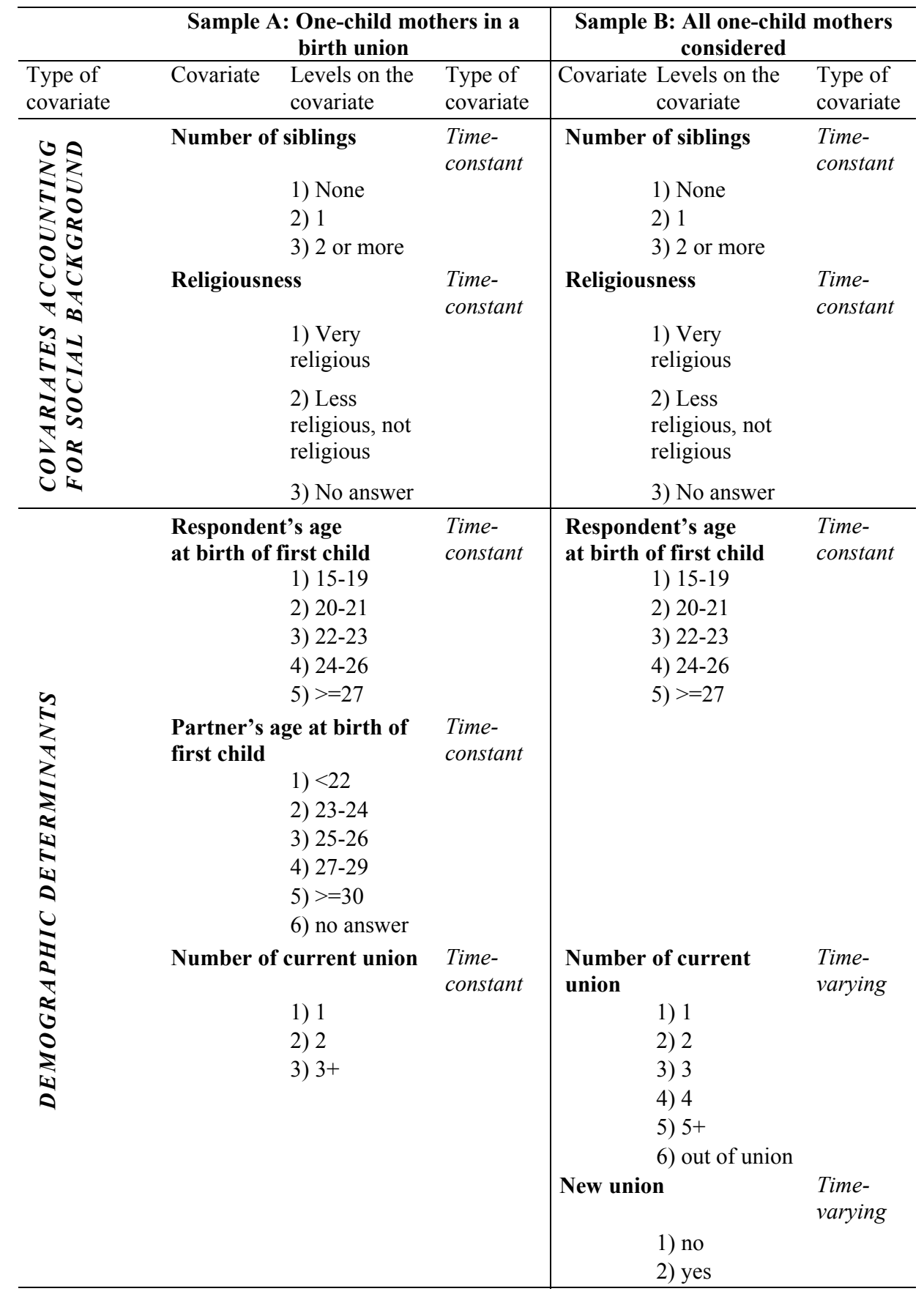


Table A3 (continued)

\begin{tabular}{|c|c|c|c|c|c|}
\hline & \multicolumn{3}{|c|}{$\begin{array}{l}\text { Sample A: One-child mothers in a } \\
\text { birth union }\end{array}$} & \multicolumn{2}{|c|}{$\begin{array}{l}\text { Sample B: All one-child mothers } \\
\text { considered }\end{array}$} \\
\hline $\begin{array}{l}\text { Type of } \\
\text { covariate }\end{array}$ & Covariate & $\begin{array}{l}\text { Levels on the } \\
\text { covariate }\end{array}$ & $\begin{array}{l}\text { Type of } \\
\text { covariate }\end{array}$ & $\begin{array}{c}\text { Covariate Levels on the } \\
\text { covariate }\end{array}$ & $\begin{array}{l}\text { Type of } \\
\text { covariate }\end{array}$ \\
\hline  & \multicolumn{3}{|c|}{$\begin{array}{l}\text { 1) Cohabiting } \\
\text { 2) Married }\end{array}$} & \multicolumn{2}{|c|}{$\begin{array}{l}\text { 1) Not in a union } \\
\text { 2) Cohabiting } \\
\text { 3) Married }\end{array}$} \\
\hline \multirow{4}{*}{ 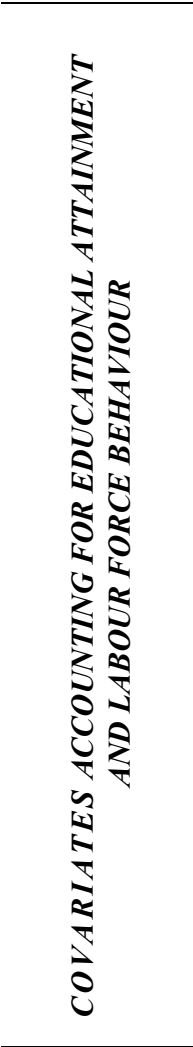 } & \multicolumn{3}{|c|}{$\begin{array}{ll}\text { Education attained by } & \text { Time- } \\
\text { partner at start of birth } & \text { constant } \\
\text { union }\end{array}$} & $\begin{array}{l}\text { Education attained by } \\
\text { respondent } \\
\text { 1) Basic } \\
\text { 2) Lower secon } \\
\text { 3) Upper } \\
\text { 4) Tertiary }\end{array}$ & $\begin{array}{l}\text { Time- } \\
\text { varying } \\
\text { ary }\end{array}$ \\
\hline & \multicolumn{3}{|c|}{$\begin{array}{ll}\text { Respondent's labour } & \text { Time- } \\
\text { force attachment, age } 15 & \begin{array}{l}\text { constant } \\
\text { to start of birth union }\end{array}\end{array}$} & $\begin{array}{l}\text { Mother's labour force } \\
\text { attachment, } \\
\text { age } 15 \text { to first birth } \\
\text { 1) No employm } \\
\text { 2) Some emplo }\end{array}$ & $\begin{array}{l}\text { Time- } \\
\text { constant } \\
\text { ment }\end{array}$ \\
\hline & \multicolumn{3}{|c|}{$\begin{array}{l}\text { Respondent's labour } \\
\text { force attachment, start of } \begin{array}{l}\text { Time- } \\
\text { constant }\end{array} \\
\text { hirth union to first hirth } \\
\text { 1) No employment } \\
\text { 2) Some employment }\end{array}$} & \multicolumn{2}{|c|}{$\begin{array}{l}\text { 1) No employment } \\
\text { 2) Some employment }\end{array}$} \\
\hline & \multicolumn{2}{|c|}{$\begin{array}{l}\text { Respondent's current } \\
\text { job status }\end{array}$} & $\begin{array}{l}\text { 1) Not employed } \\
\text { 2) Employed }\end{array}$ & \multicolumn{2}{|c|}{$\begin{array}{l}\text { 1) Not employed } \\
\text { 2) Employed }\end{array}$} \\
\hline 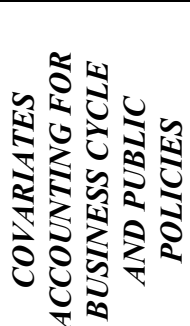 & Calendar & $\begin{array}{l}\text { 1) } 1960-1973 \\
\text { 2) } 1974-1979 \\
\text { 3) } 1980-1987 \\
\text { 4) } 1988-1990 \\
\text { 5) } 1991-1992 \\
\text { 6) } 1993-1996\end{array}$ & $\begin{array}{l}\text { Time- } \\
\text { varying }\end{array}$ & 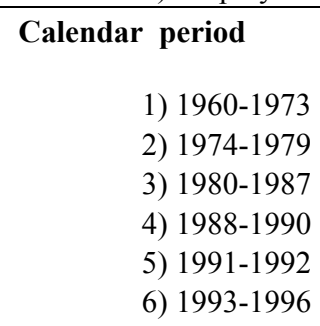 & $\begin{array}{l}\text { Time- } \\
\text { varying }\end{array}$ \\
\hline
\end{tabular}

